\title{
Inter-El Niño variability and its impact on the South American low-level jet east of the Andes during austral summer - two case studies
}

\author{
G. A. M. Silva and T. Ambrizzi \\ Department of Atmospheric Sciences, University of São Paulo, São Paulo, Brazil \\ Received: 12 May 2005 - Revised: 12 January 2006 - Accepted: 16 January 2006 - Published: 8 March 2006
}

\begin{abstract}
The impact of the maximum convection location over eastern and central Equatorial Pacific over the intensity and positioning of the South American Low-Level Jet east of the Andes (SALLJ) during the austral summer was investigated. The Bonner criteria 1 was applied to the NCEPNCAR circulation fields during the El Niño of 1997/1998 and 2002/2003 to identify the SALLJ episodes. The composites of the atmospheric circulation over the South America during El Niño events showed that the SALLJ can be influenced by small displacements of the quasi-stationary Rossby waves position. During the strong El Niño event of 1997/1998 the SALLJ is maintained by the eastern trade winds. A low-level anomalous anticyclonic circulation over the central part of Brazil enhanced the wind in the nucleus of the jet and displaced its axis to the Northern Argentina and South of Brazil. However, the northern trade winds seem to maintain the SALLJ during the weak El Niño of 2002/2003. The jet was weaker and displaced more southeastward of Brazil than during the strong event.
\end{abstract}

\section{Introduction}

This research is focused on the observational analyse of the remote impact of the inter El Niño variability in the SALLJ development. During austral summer (December-JanuaryFebruary) there are some meteorological systems that can have an important impact on the precipitation regime of the SA continent. One of these systems is the Low Level Jet east of the Andes or the South American Low Level Jet (SALLJ) defined as a subsynoptic system of wind with high speed, with maximum velocity around $2 \mathrm{~km}$ height, horizontal extension of hundreds of kilometers and that occurs in all seasons (e.g., Stensrud, 1996; Douglas et al., 2000; Marengo et al., 2004; Misra et al., 2000; Berbery and Barros, 2002). This system seems to be responsible for transporting large quanti-

Correspondence to: G. A. M. Silva

(gyrlene@model.iag.usp.br) ties of water vapor from the Amazon region into central and southern South America mainly during summer (e.g., Berri and Inzunza, 1993; Nogués-Paegle and Mo, 1997; Saulo and Nicolin, 2000; Silva Dias, 2000; Marengo et al., 2004), generating turbulence through shear and participating actively as trigging mechanism for the formation of severe storm over the Southeast/South of Brazil and Northern Argentina (e.g., Velasco and Fritsch, 1987; Guedes and Silva Dias, 1985; Salio et al., 2002; Nicolini et al., 2002; Nieto Ferreira et al., 2003).

Some authors have registered the existence of SALLJ in the globe, and the most known are the jets of the Great North American Plain, whose climatology was established by Bonner (1968). Bonner established criteria for identification of the jets, based in statistical analyses applied over two years of data from 47 stations distributed in the United States. The jets studied by Bonner are responsible for the transport of moisture from Gulf of Mexico to the center of the United States, associated with an intense convection like monsoon during the summer.

A few studies using observations from radiosonde and pilot balons from the LBA WET AMC (Silva Dias et al., 2002) and the SALLJEX field experiment (Vera et al., 2005), as well as using reanalyses from the National Center for Environmental Prediction (NCEP) have shown the occurrence of SALLJ in different seasons of the year (Paegle, 1998; Douglas et al., 1998; Douglas et al., 2000; Saulo et al., 2000; Misra et al., 2000; Marengo et al., 2004). However it is in the summer that most intense events bringing moisture from the Amazon region occur. Sugahara et al. (1994) have shown through the analysis of eight summers that, in approximately $30 \%$ of the days, the northern flow east of Andes acquired characteristic of low level jet (with speed superior to $8 \mathrm{~ms}^{-1}$ and a vertical shear between 850 and $700 \mathrm{hPa}$ ). In the average of the days with jets, the maximum speed reached $13 \mathrm{~ms}^{-1}$ in $850 \mathrm{hPa}$. The authors compared the days with and without jets through the difference in the Outgoing Longwave Radiation (OLR) field, and they showed that the convection was intense and concentrated in the days with jets and when the 


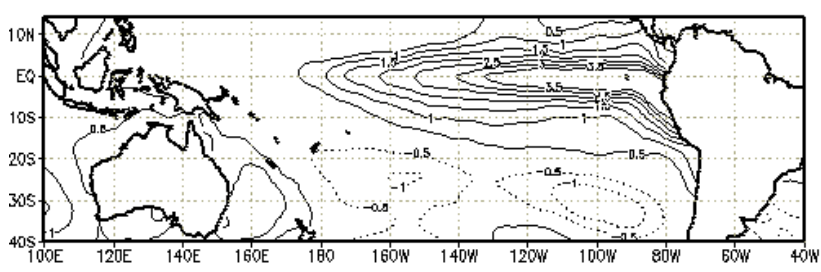

(a)

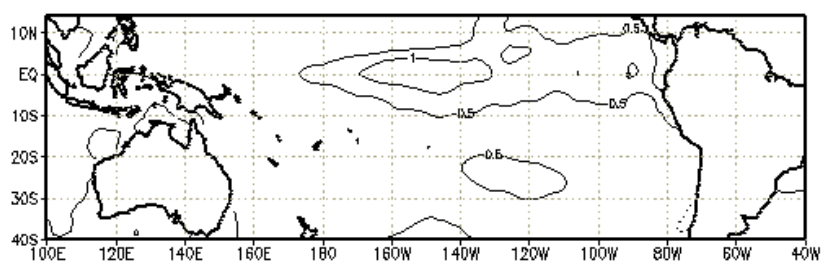

(b)

Fig. 1. Sea Surface Temperature anomaly $\left({ }^{\circ} \mathrm{C}\right)$ observed during austral summer (DJF) for the El Niño years of (a) 97/98 and (b) $02 / 03$. Contour interval is $0.5^{\circ} \mathrm{C}$ and negative values are dotted.

subtropical Mesoscale Convective Complexes (MCC) typically occurs. They have also suggested some relationship between LLJ intensity and the South Atlantic Convergence Zone (SACZ). Marengo et al. (2004) applied the Bonner criterion 1 in fields of atmospheric circulation and moisture of NCEP reanalyzes for the period of 1950-2000 (Bonner, 1968) and found that the largest occurrence of jets occur during December to February on the Bolivian region, and is usually followed by the weakening of the SACZ.

Remote processes of large-scale in association with mesoscale processes can explain the precipitation regime over South America (SA). Drumond and Ambrizzi (2003) studied the El Niño (EN) events of 1982/83, 86/87, 91/92 and 97/98, and verified that each episode has a specific SST forcing and atmospheric circulation and therefore a different impact on the Americas precipitation. In the SA, the inter El Niño variability, i.e., the difference between each event, indicates rainfall anomalies mainly over Uruguay, Southern Brazil and Northern Argentina as found by previous studies, though with different intensities and sometimes even opposite signal. Magaña and Ambrizzi (2005) have suggested that the location of the spatial structure of anomalous convective forcing in the tropical Pacific can affect the phase and amplitude of quasi-stationary circulations over the SA and, therefore, the regions of maximum rain intensity.

\section{Data and methodology}

Data from National Center for Environmental Prediction (NCEP) (Kalnay et al., 1996) have been used for (DecemberFebruary) covering the 1950-2003, initiating in December of the initial year (0) and finishing in February of the following year (1). The data include: four time daily data - zonal and meridional winds at 200 and $850 \mathrm{hPa}$ levels and Sea Level Pressure (SLP) on $2.5^{\circ}$ grid; monthly mean - streamfunc-
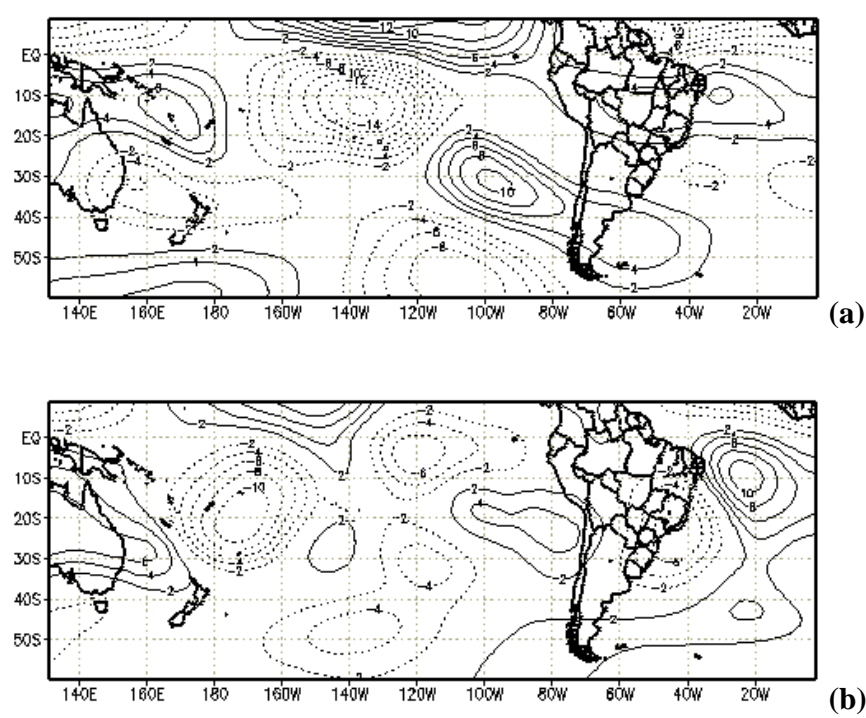

(b)

Fig. 2. Streamfunction anomaly $\left(\mathrm{m}^{2} \mathrm{~s}^{-1}\right)$ at level of $200 \mathrm{hPa}$ observed during austral summer (DJF) for the El Niño years of (a) $97 / 98$ and (b) $02 / 03$. Contour interval is $2 \times 10^{-6} \mathrm{~m}^{2} \mathrm{~s}^{-1}$ and negative values are dotted.

tion at the 0.21 sigma level (about $200 \mathrm{hPa}$ level). In addition, Sea Surface Temperature (SST) monthly mean for NOAA Extended Reconstructed SST (Wooddruf et al., 1987) on $2.0^{\circ} \times 2.0^{\circ}$ longitude-latitude grid was also used.

The El Niño (EN) events of 1997/1998 and 2002/2003 selected for this study are classified by CPC/NOAA (www. cpc.ncep.noaa.gov) as strong and weak, respectively. The methodology of Marengo et al. (2004) was applied to wind data in order to select the SALLJ episodes. It was assumed that the axis of the jet is located around $850 \mathrm{hPa}$, in the Santa Cruz - Bolivia $\left(17.75^{\circ} \mathrm{S} ; 63.06^{\circ} \mathrm{W}\right)$ region where the authors observed the maximum activity of the system during the summer. The Bonner criterion 1 (Bonner, 1968) was applied to define the occurrence of SALLJ and it is based on the following conditions: (a) the meridional wind must be from north; (b) the magnitude of the wind in $850 \mathrm{hPa}$ must be larger or equal to $12 \mathrm{~ms}^{-1}$; and (c) the vertical wind shear should be larger or equal to $6 \mathrm{~ms}^{-1}$ per km between 850 and $700 \mathrm{hPa}$.

The remote El Niño signal on the atmospheric circulation on SA was investigated by composites of SST anomalies over the Equatorial Pacific and streamfunction anomalies. The regional circulation associated to the SALLJ was examined through the composites of SLP, wind anomalies at $850 \mathrm{hPa}$ and $200 \mathrm{hPa}$ anomalies. The composites were constructed in accordance with the intensity of the EN events, and considering the fields daily mean during the maximum SALLJ activity. A Student's T test (Harrison and Larkin, 1998) was applied to the composites to determine the areas of statistical significance. The anomaly of the composite was accepted with the confidence level of $95 \%$. 


\section{El Niños events of $1997 / 1998$ and 2002/2003: case studies}

Figure 1 shows the SST anomaly for the strong (1997/1998) and weak (2002/2003) El Niño events. Anomalies higher than $+3.0^{\circ} \mathrm{C}$ centered on the Eastern Equatorial Pacific Ocean is clearly observed for the strong EN episode (Fig. 1a). On the other hand, during the weak event values around $+1.0^{\circ} \mathrm{C}$ are centered around on $150^{\circ} \mathrm{W}$ to the west of the strong one (Fig. 1b).

Figure 2 shows the composites of the streamfunction anomaly (i.e., with zonal mean removed) at $200 \mathrm{hPa}$ level for the strong and weak EN events. In general, one can see quasi-stationary Rossby waves spanning poleward from the Equatorial Pacific in the upper troposphere as a result of anomalously intense convective activity. Magaña and Ambrizzi (2005) have suggested that the location of the spatial structure of anomalous convective forcing in the tropical Pacific can affect the phase and amplitude of quasi-stationary circulations and, therefore, the regions of maximum rain intensity. During the strong event (Fig. 2a) the wave train patterns showed higher amplitude and more defined wave structured than in the weak event (Fig. 2b).

The wind field climatological patterns at low and high levels over the SA are showed in Fig. 3. At $850 \mathrm{hPa}$ level (Fig. 3a) near the equator the trade winds with magnitude about $11 \mathrm{~ms}^{-1}$ penetrated in the SA. Near the Andes the winds are deflected northeastward going towards the southeast and the low level jet maximum is about $8 \mathrm{~ms}^{-1}$. Over the south of Brazil it is observed the confluence of the winds coming from the subtropical Atlantic anticyclone and low level jet. At $200 \mathrm{hPa}$ the Bolivian High at $17^{\circ} \mathrm{S} ; 65^{\circ} \mathrm{W}$ reinforce the Subtropical Jet (SJ) over the continent between $40^{\circ} \mathrm{S}$ and $50^{\circ} \mathrm{S}$.

The Rossby wave pattern showed in Fig. 2 shows influence the atmospheric circulation. The composites of atmospheric circulation for the days with SALLJ maximum activity according the Bonner criteria 1 during the EN of $97 / 98$ and 02/03, respectively, are illustrated in Figs. 4 and 5. These figures show the SLP and low-level wind anomaly at $850 \mathrm{hPa}$ and the high-level wind anomaly at $250 \mathrm{hPa}$. For the strong EN event one can see the dominance of a lower pressure center over the La Plata basin (Northern Argentina, Paraguay, south of Bolivia and Brazil) and intense LLJ in the area (Fig. 4a). In the upper level, the SJ streak (Fig. 4b) is larger and stronger than the climatological pattern (Fig. 3b). In fact, presence of the LLJ, the lower pressure and the SJ over this region, contributes to the enhanced precipitation there, as pointed out by many studies before (Grimm et al., 1998; Magaña and Ambrizzi, 2005 and references therein). On the other hand, during weak EN events, the low pressure center is less defined and the LLJ is displaced northward (Fig. 5a), being around the climatological position of the SACZ. The $\mathrm{SJ}$ is weaker when compared to the previous EN and the core of its maximum intensity is displaced to the South American coast and therefore unfavourable to convective activity over the La Plata basin. Recently, Liebmann et al. (2004) have

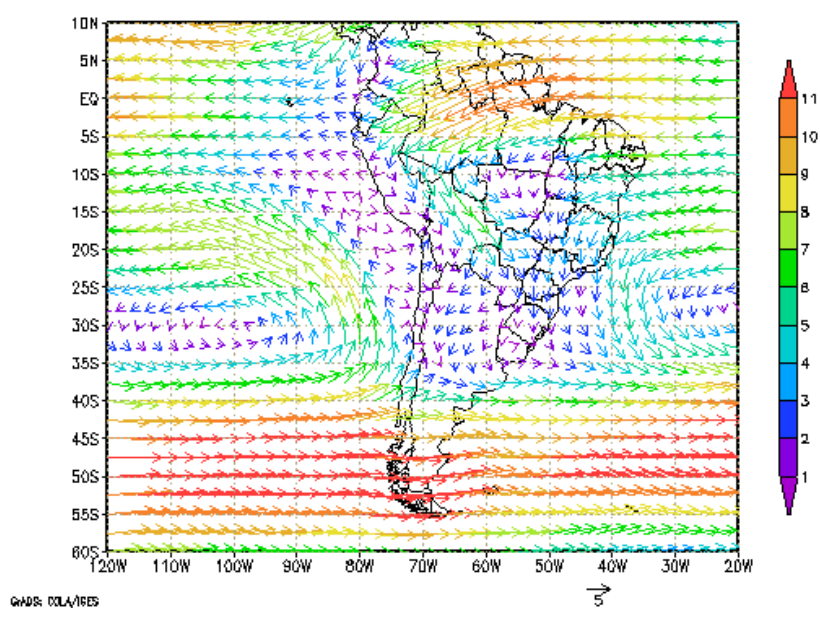

(a)

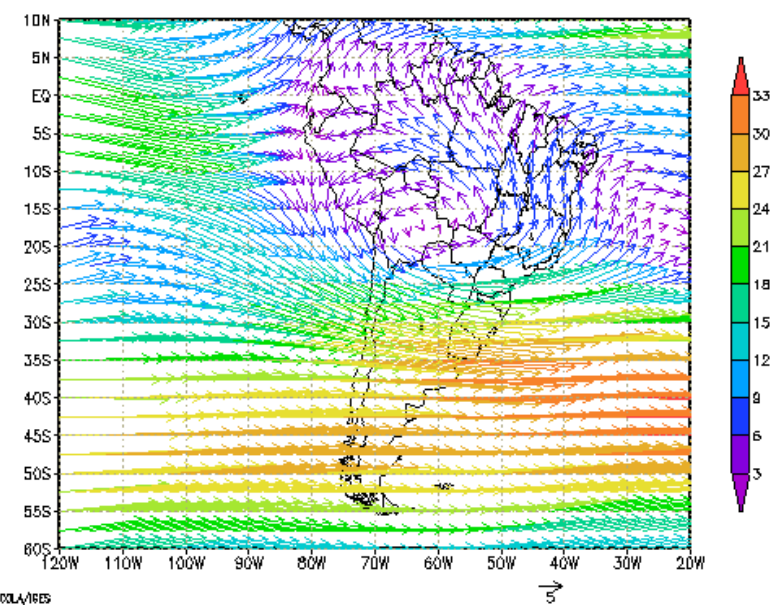

(b)

Fig. 3. Climatological vector wind $\left(\mathrm{ms}^{-1}\right)$ for DJF 1950-2003 at: (a) $850 \mathrm{hPa}$ and (b) $200 \mathrm{hPa}$.

suggested that on a daily time scale, a preference for rain in the SACZ coincides with a weak jet and dry conditions downstream of it, and vice versa.

From the above analysis it seems that the position and intensity of the SALLJ may vary depending on the strength of an EN event. This result suggests that the quasi-stationary Rossby wave pattern generated due the thermal forcing over the Equatorial Pacific can be a possible mechanism that modulate o SALLJ. Further studies considering a large number of EN events are still necessary before any conclusion can be drawn.

\section{Conclusions}

The influence of SST variability presented in the Equatorial Pacific and the internal dynamic of the atmosphere can modulate the south-american continent climate. The observational case studies for the strong El Niño of 1997/1998 and weak El Niño of 2002/2003 showed the pattern of a Rossby wave train that emanates from the Eastern Central Equatorial Pacific crosses the south of SA and goes 

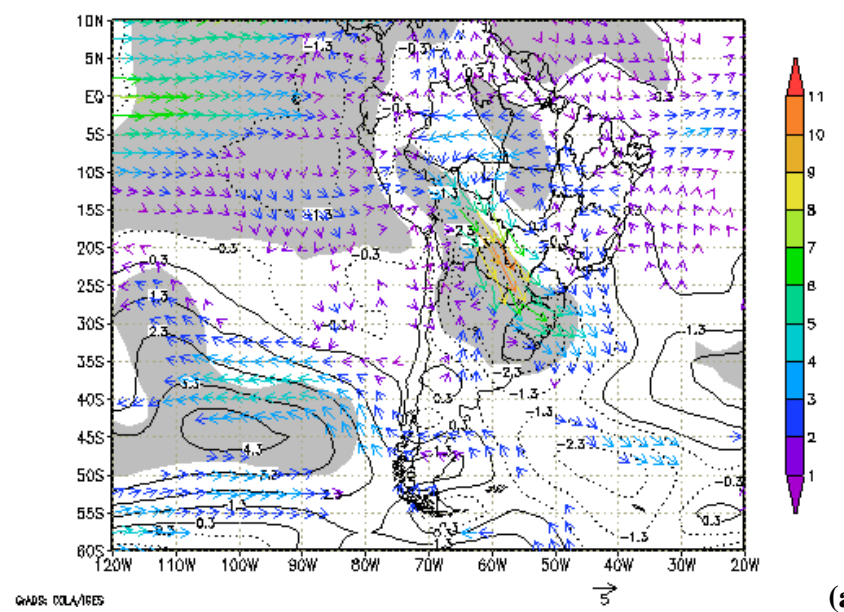

(a)

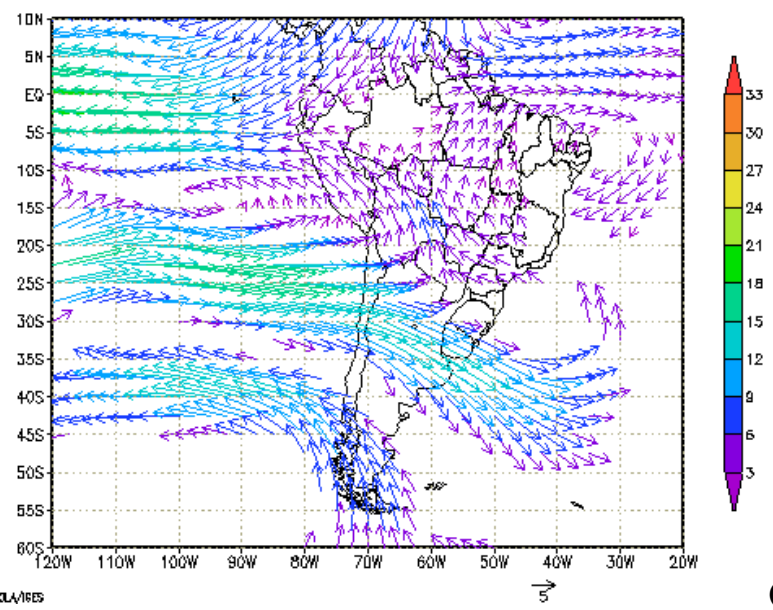

(b)

Fig. 4. Composites for the days with SALLJ maximum activity during the El Niño of 97/98: (a) SLP (hPa) and vector wind anomaly $\left(\mathrm{ms}^{-1}\right)$ at $850 \mathrm{hPa}$ level and (b) vector wind anomaly $\left(\mathrm{ms}^{-1}\right)$ at $200 \mathrm{hPa}$ level. Contour interval is $1 \mathrm{hPa}$ and the negative contours are dotted. The wind and the shaded area indicate statistically significant anomalies at the confidence level of $95 \%$.

towards low latitudes. The daily SALLJ composites for the two El Niño episodes showed that the position and amplitude of the maximum activity of the LLJ may vary depend on the positioning of the quasi-stationary Rossby waves over the south-american continent. During the strong EN event, the composites showed that SALLJ follows a path slightly southward the climatological low level wind circulation, with the jet maximum over the Northern Argentina, Paraguay and South of Brazil. During the weak event the main axis of the SALLJ moves to the north, close to the SACZ climatological position had been also weaker than the previous event. In summary, the case studies suggest that the atmosphere basic state can be modified depending on the intensity of the El Niño event. Therefore, the position of the quasi-stationary waves may also vary and it can influence the position and intensity of the SALLJ. Further studies considering a large number of EN events are still necessary before any conclusion can be drawn.

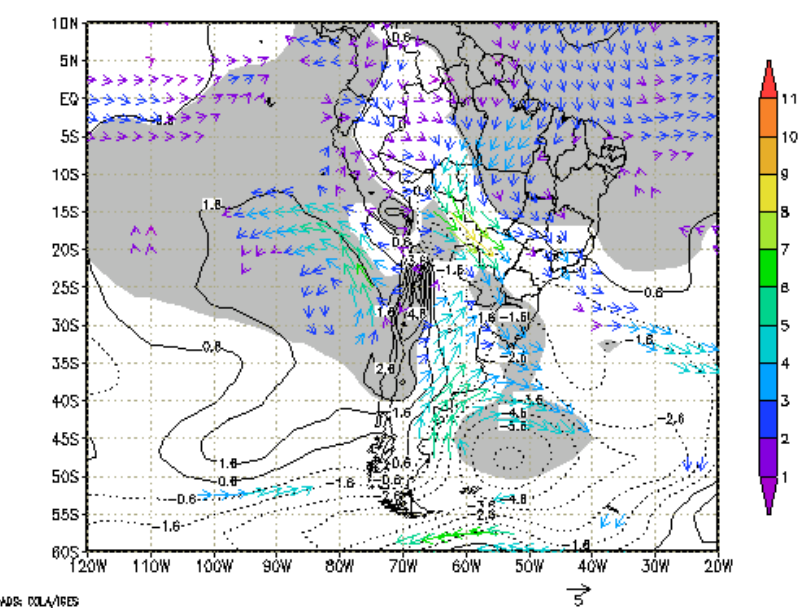

(a)

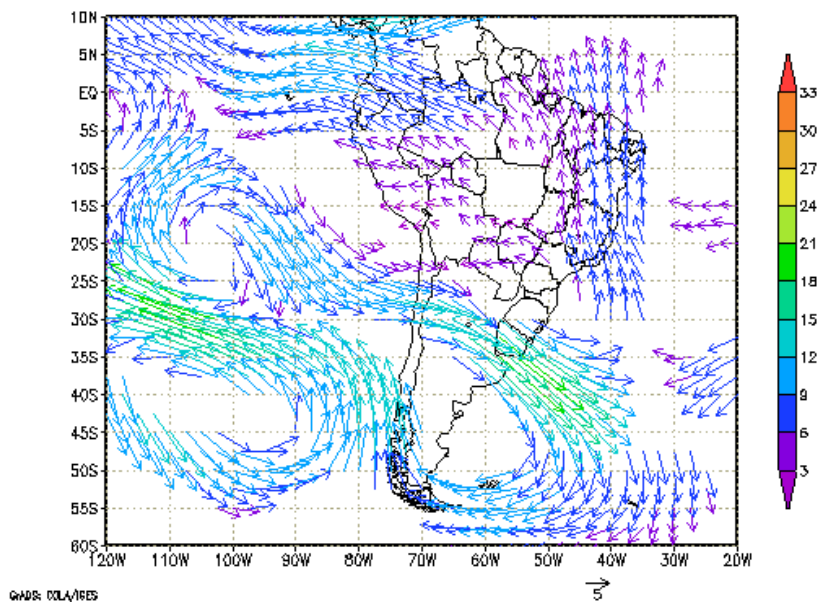

(b)

Fig. 5. The same as Fig. 4, but during the El Niño of 02/03.

Acknowledgements. This work is part of G. A. M. Silva M.Sc. Dissertation sponsored by Fundação de Amparo à Pesquisa do Estado de São Paulo - FAPESP at University of São Paulo (2002/10741-3). We would like to thank FAPESP by the support in the project 2001/13816-1 and the Conselho Nacional de Desenvolvimento Científico e Tecnológico - CNPq (302459/2002-2). This work was partially supported by Inter America Institute for Global Change Research - IAI (CRN055).

Edited by: P. Fabian and J. L. Santos

Reviewed by: M. McPhaden and another anonymous referee 


\section{References}

Berri G. J. and Inzunza B. J.: The effect of the low-level jet on the poleward water vapour transport in the central region of South America, Atmos. Environ., 27A, 335-341, 1993.

Berbery, E. H. and Barros, V. R.: The Hydrologic Cycle of the La Plata Basin in South America, J. Hydromet., 3, 630-645, 2002.

Bonner, W. D.: Climatology of the Low Level Jet, Mon. Wea. Rev., 96, 833-850, 1968.

Douglas, M. W., Valdez-Manzanilla, A., and Cueto, R. G.: Diurnal Variation and Horizontal Extent of the Low-Level Jet over the Northern Gulf of California, Mon. Wea. Revi., 126, 2017-2025, 1998.

Douglas, M. W., Peña, M., and Villarpando, R.: Special observations of the low level flow over eastern Bolivia during the 1999 atmospheric mesoscale campaign, Extended Abstracts of the 6th Inter. Conf. on Southern Hemisphere Meteorology and Oceanography, 3-7 April 2000, Santiago, Chile, 157-158, 2000.

Drumond, A. R. M. and Ambrizzi, T.: Estudo observacional e numérico da variação da circulação atmosférica nas Américas em episódios extremos da Oscilação Sul, Revista Brasileira de Meteorologia, 18, n. 1., 2003.

Guedes, R. L. and Silva Dias, M. A. F.: The observed synoptic scale structure in the presence of mesoscale convective complexes over South America, 2nd Meeting of the Brazil-USA Cooperative Program on the Role of Convection in the Amazon Region, São José dos Campos, São Paulo, 5-7 August 1985.

Grimm, A. M., Ferraz, S. E. T., and Gomes, J.: Precipitation anomalies in Southern Brazil associated with El Niño and La Niña events, J. Climate, 11, 2863-2880, 1998.

Harrison, D. E. and Larkin, N. K.: El Niño-Southern Oscillation sea surface temperature and wind anomalies, 1946-1993, Rev. Geophys., 36(3), 353-399, 1998.

Liebmann, B., Kiladis, G. N., Vera, C. S., and Saulo, A. C.: Subseasonal Variations of Rainfall in South America in the Vicinity of the Low-Level Jet East of the Andes and Comparison to Those in the South Atlantic Convergence Zone, J. Climate, 17, 38293842, 2004.

Paegle, J.: A comparative review of South American low level jets, Meteorologica, 3,73-82, 1998.

Magaña, V. and Ambrizzi, T.: Dynamics of subtropical vertical motions over the Americas during El Niño boreal winters, Atmósfera, 18(4), 211-233, 2005.

Marengo, J. A., Soares, W. R., Saulo, C., and Nicolini, M.: Climatology of the Low-Level Jet east of the Andes as derived from the NCEP reanalyses, J. Climate, 17, 2261-2280, 2004.

Misra, V., Dirmeyer, P., Kirtman, B., Huang, H., and Kanamitsu, M.: Regional simulation of Interannual Variability over South America, COLA Technical Report, 85, 42 pp., 2000.
Nicolini, M., Saulo, A. C., Torres, J. C., and Salio, P.; Enhanced precipitation over southeastern South America related to strong low-level jet events during austral warm season. Meteorologica, Special Issue for the South American Monsoon System, 27, 5969, 2002.

Nieto-Ferreira, R. N., Rickenbach, T. M., Herdies, D. L., and Carvalho, L. M. V.: Variability of South American Convective Cloud Systems and Tropospheric Circulation during January-March 1998 and 1999, Mon. Wea. Rev., 131, 961-973, 2003.

Nogués-Paegle, J. and Mo, K.-C.: Alternating wet and dry conditions over South America during summer, Mon. Wea. Rev., 125, 279-291, 1997.

Salio, P., Nicolini, M., and Saulo, A. C.: Chaco Low-level jet events characterization during the austral summer season, J. Geophys. Res., 107, D24, 4816, doi:10.1029/2001JD001315, 2002.

Saulo, A. C., Nicolini, M., and Chou, S. C.: Model characterization of the South American low level flow during the 1997-1998 spring-summer season, Clim. Dyn., 16, 867-881, 2000.

Silva Dias, P. L.: The role of latent heat release in the dynamics of the LLJ's along the Andes, Preprints of the 6th International Conference on Southern Hemisphere Meteorology and Oceanography, 3-7 April 2000, Santiago, Chile, 2000.

Silva Dias, M., Silva Dias, P., Rutledge, S., Lima, M. A., Gomes, A., Antonio, M., Fisch, G., and Rocha, H.: Case study of multiple convective lines during the WET AMC/LBA and TRMM/Brazil, J. Geophys. Res., 107, 39.1-39.20, in press, 2002.

Stensrud, D. J.: Importance of low-level jets to climate: A review, J. Climate, 9, 1698-1711, 1996.

Sugahara, S., Rocha, R. P., and Rodrigues, M. L: Condições atmosféricas de grande escala associadas a jato de baixos níveis na América do Sul, VIII Congresso Brasileiro de Meteorologia SBMET, Anais 2, 573-577, 1994.

Velasco, I. and Fritsch, J.: Mesoscale convective complexes in the Americas, J. Geophys. Res., 92, 9591-9613, 1987.

Vera, C., Higgins, W., Amador, J., Ambrizzi, T., Garreaud, R., Gochis, D., Guztler, D., Lettenmaier, D., Marengo, J. A., Mechoso, C. R., Nogues-Paegle, J., and Zhang, C.: A Unified View of the American Monsoon Systems, J. Climate, in press, 2005.

Woodruff, S. D., Slutz, R. J., Jenne, R. L., and Steuder, P. M: Comprehensive oceanatmosphere data set. Bull. Am. Meteorol. Soc., 68, 1239-1250, 1987.

Kalnay, E., Kanamitsu, M., Kistler, R., Collins, W., Deaven, D., Gandin, L., Iredell, M., Saha, S., White, G., Woollen, J., Zhu, Y., Chelliah, M., Ebisuzaki, W., Higgins, W., Janoviak, J., Mo, K. C., Ropelewski, C., Wang, J., Leetmaa, A., Reynolds, R., Roy, J., and Joseph, D.: The NCEP/NCAR 40-year Reanalysis Project, Bulletin of the American Meteorological Society, 77, 3, 437471, 1996 